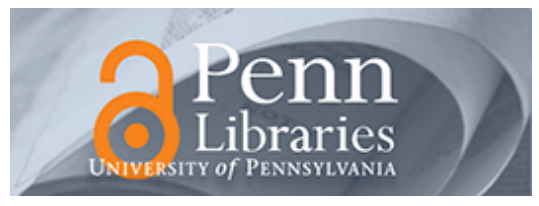

Studies in Visual Communication

Volume 10

Issue 4 Fall 1984

Article 3

1984

\title{
Vitagraph Before Griffith: Forging Ahead in the Nickelodeon Era
}

Jon Gartenberg

\section{Recommended Citation}

Gartenberg, J. (1984). Vitagraph Before Griffith: Forging Ahead in the Nickelodeon Era. 10 (4), 7-23.

Retrieved from https://repository.upenn.edu/svc/vol10/iss4/3

This paper is posted at ScholarlyCommons. https://repository.upenn.edu/svc/vol10/iss4/3

For more information, please contact repository@pobox.upenn.edu. 


\section{Vitagraph Before Griffith: Forging Ahead in the Nickelodeon Era}




\title{
Vitagraph before Griffith: Forging Ahead in the Nickelodeon Era
}

\author{
Jon Gartenberg
}

\section{Researching Vitagraph}

Although we now have a greater understanding of the state of film narrative before D. W. Griffith began directing films in $1908,{ }^{1}$ little is known about the Vitagraph Company of America, an important film company during the rise of the nickelodeon era, 1905-1907. Much of the research on early American film companies has centered on Edison and Biograph and on the films of Edwin Porter and Griffith, rather than on Vitagraph. Primary Biograph and Edison films and written records are readily available, whereas Vitagraph documents and films are scarcer. For Biograph and Edison, these materials include the paper print collection at the Library of Congress and the prints preserved from original negatives in The Museum of Modern Art film archives; Biograph Bulletins from 1896-1913 reproduced in two volumes microfilm of the original Biograph production records (indicating such details as production numbers, titles photographers, dates and places photographed, and lengths of films); depositions of the Edison company at the Edison National Historic Site and in courts in New York and New Jersey; and written copyright deposit records at the Library of Congress. These resources make possible a systematic and chronological study of the films produced by Biograph and Edison and the documents relating to their making, as well as of the battles between the two companies to establish control over the industry. There are thus many publications about Biograph and Edison, and Griffith and Porter. ${ }^{2}$

The research situation differs greatly for Vitagraph. Whereas relatively complete production information exists for Biograph and Edison in Washington, New York, and New Jersey, important Vitagraph records are scattered among New York City, Rochester, Washington, Los Angeles, London, and Paris. More significant than the wide geographical distribution of the Vitagraph materials is the fact that many Vitagraph company documents are missing. A fire in the summer of 1910 destroyed many of the company's negatives and papers. Only a few Vitagraph Bulletins prior to November 1, 1909, exist. Where personal and corporate papers, letters, and like material exist, they frequently conflict. Only sixteen of the 121

Jon Gartenberg is Assistant Curator in the Museum of Modern Art Department of Film. His special interests include archival issues, early cinema, and experimental film. He has lectured about these and other aspects of film history both in the United States and abroad, and his articles have appeared in numerous publications including Cinema Journal, Iris, Quarterly Review of Film Studies, Films in Review, and the Historical Journal of Film Radio and Television.
Vitagraph productions (13 percent) released between September 1905 and December 31, 1907, survive. A number of these prints are missing key scenes. The copy of The Green Goods Men (January 1906) lacks the ending of the film, which shows the ingenious resolution of the chase in which "the Green Goods Men crawl down the wrong chimney and land in a police station."3 In Liquid Electricity (September 1907), the inventor's galvanic fluid, when sprayed on people, moves them to quick action, resulting in many comic scenes. The surviving prints are missing the final shot(s) in which the professor "returns to laboratory disgusted, smashes bottle which explodes, blowing the inventor into bits", ${ }^{4}$ a scene that links it to the explosion genre films of earlier years, such as The Finish of Bridget McKeen (1901). Paper prints of Vitagraph productions are now being copied, but they are only fragmentary records of the films. Unlike the Biograph and Edison paper prints, which are complete, Vitagraph deposited only about thirty frames for each different scene of a film.

For all these reasons, Vitagraph's importance has been pieced together from scattered documents, analysis of the existing films, comparison with productions from other companies, the work of other scholars in early cinema, and the study of trade papers and newspapers, such as the New York Clipper, Views and Film Index, Moving Picture World, and the Brooklyn Daily Eagle. What emerges is a picture of a company that was in the forefront of the rapid changes in the industry during the rise of the nickelodeon era, 1905-1907. Vitagraph developed an alternative model for the manufacture of films that contrasted with Biograph's. The company's building of a new studio in 1905 enabled Vitagraph to become a leader in the method, quantity, kinds, and style of films made. By 1907 at Vitagraph, there was a shift to a new way of telling dramatic stories through the full use of the space in interior shooting and through the emergence of parallel editing.

\section{Vitagraph Studio Production}

On June 19, 1905, the first storefront Nickelodeon Theatre opened in Pittsburgh (Allen 1979:2). In the ensuing years, the number of sites showing films exclusively rose dramatically: "The wonderful growth in number of so-called 'storeshows' and 'Nickelodeons' in the past twelve months has been due to a great extent to the patronage accorded this class of amusement by the women and children." 5 The explosion of the nickelodeons brought about a great increase in the number of films produced and a change in the kinds of films made. The quality of the films improved as well. In August 1905, just two 
months after the Pittsburgh nickelodeon opened, Vitagraph broke ground for a studio at East Fifteenth Street and Locust Avenue in Brooklyn, which was completed in August 1906. ${ }^{6}$ Vitagraph built "several stages for the taking of special photographic effects." "7 This use of the studio was enormously signifi cant because it enabled the Vitagraph Company to establish much greater artistic control over the production of its films

Shooting in the studio greatly improved control over the mise-en-scène. In The 100 to 1 Shot or, a Run of Luck, released just before the studio's completion, scenes of the farmer and his family in their house in shots 2,23 , and 25 are photographed in a full-length view that reveals floorboards in the foreground and sparse furniture and a few characters in front of a painted background. The protagonists and furniture cast distinct shadows onto the ground. In The Green Goods Men, a comedy chase released earlier in 1906, deep shadows intrude upon similarly composed "interior" scenes. With the opening of the studio came "a complete outfit of Cooper Hewitt lights. ... The entire roof and upper part of the building is covered with a specially designed prismatic glass. This construction of glass diffuses and intensifies the rays of light so that shadows are not perceptible." ${ }^{18}$ The production and release of $A$ Midwinter Night's Dream or Little Joe's Luck (December 1906) just a few months after the studio began operation shows the marked improvement in lighting made possible by the studio. The interior scenes of the dining room, livingroom, and bedroom betray no shadows. Similarly, in the interior scenes of Foul Play or, a False Friend (January 1907), no shadows are cast. In Liquid Electricity (September 1907), when the inventor sprays the galvanic fluid on himself, his laboratory becomes more brightly illuminated. ${ }^{9}$

During the next decade, Vitagraph's rapid studio expansion continued, a good indication of its success. By the end of 1908 its facilities covered "two full blocks, where three studios are in operation and two more are being erected."10 Meanwhile, Biograph was restricted to a small studio on Fourteenth Street in Manhattan until the summer of 1913. By 1916, Vitagraph's assets included two acres of studios and factories in Brooklyn, studios in Bay Shore, Long Island, eighteen acres of plants in Los Angeles and Paris, and a business office and rental department in London. ${ }^{11}$

While Biograph was shifting from a cameraman to director-cameraman model of film production, Vitagraph was developing a system with a central producer. ${ }^{12}$ Biograph employed four cameramen in 1905 and three in 1906 (Spehr 1980:419-420); from early 1908 through 1909 at Biograph, Griffith was the sole director and Billy Bitzer the only cameraman.
While the loss of D. W. Griffith to the [Biograph] company [in 1913] was a great one, [it was not] the only factor in the demise of Biograph. The company did not significantly increase the staff and the means for production while he was still there, and after he left the much increased staff did not approach his productivity. (Bowser 1981:8)

In contrast, Vitagraph, with its new studio, was moving toward a system of increased production of films through a central producer, J. Stuart Blackton, with individual directors working under him. Before the studio was built, Blackton was for the most part the sole Vitagraph filmmaker. ${ }^{13}$ When the company's facilities expanded, others were brought in to direct, and the company's founders were increasingly involved in administration. From 1906 to 1910, the number of directors increased to at least half a dozen, including William Ranous, Van Dyke Brooke, Charles Kent, Larry Trimble, and others. ${ }^{14}$ Vitagraph's, more than Biograph's, method of operating a film company became the model for increased production of films for other studios. In the words of Georges Sadoul, "The system of organization at Vitagraph where the artistic director supervised several directors perhaps emanated from Pathé-Zecca's method, but it was [Vitagraph's] model which Thomas Ince and many others imitated after 1912"' (1951:65, au.'s transl.).

Early on, Vitagraph also established a model of production wherein the process of making the film was divided among various individuals. By September 1906 at Vitagraph, the functions of the writer, "stage manager," scenery painters, and actors were differentiated, although the scope of their responsibilities was wide and partially overlapping (Glover 1906). By the end of 1908, "About two hundred people in various capacities [were] constantly employed." 15 Labor was separated more clearly into specific functions, and chains of command were more firmly established, as the release of Vitagraph's Making Moving Pictures (December 1908) demonstrates. The film

opens in the private office of the Vitagraph Company, where the manuscript is being carefully considered. The studio directors enter, receive their instructions, proceed to the studio, get out the cameras, give orders about scenery, props, etc. Then we get a view of the Vitagraph actors and actresses making up for their different characters ... the studio scenes are rehearsed and photographed, showing all the necessary paraphernalia for the different effects required, as well as the rapidity with which scenes are struck and made ready by the stage hands. ${ }^{16}$

By 1911, the production process, from the reading and editing of manuscripts through the developing and editing of the completed film, was organized into autonomously functioning in-house departments. ${ }^{17}$ This method enabled Vitagraph to further increase its 
annual output of films.

In 1905 Biograph was producing more than ten times the number of films as Vitagraph and in 1906 more than three times as many. ${ }^{18}$ But in 1907, the year in which Vitagraph's studio was in full operation, the tables were turned. Vitagraph produced more than twice as many motion pictures as Biograph. In 1907 Vitagraph released an average of six films per month; by the end of 1908, the number had increased to about four films each week. While Biograph's output' between 1908 and 1913 fluctuated, Vitagraph continued to increase production steadily. In 1908 the Vitagraph Company of America "enjoy[ed] the distinction of turning out more new subjects each week than any other American concern." 19 By the time Griffith departed Biograph in 1913, Vitagraph was producing nearly twice as many films as this competitor (389 versus 198).

\section{Exhibition Practices}

By the beginning of the nickelodeon era, Vitagraph had already established an extensive exhibition network through which to show its increasing output of films. From 1897-1901, Vitagraph had a licensee relationship with the Edison Company. Uneasy as it was, it enabled Vitagraph to capitalize upon exhibition activities (Musser 1983). In 1902, the reversal of a court decision against Biograph in the preceding year removed Edison's monopoly on production. This freed Vitagraph from its licensee role, enabling the company to produce autonomously as well as to exhibit its own films. In 1904, theaters became more independent from exhibitors when they began operating their own motion picture equipment (Musser 1982). These changes in production and exhibition conditions reopened the marketplace for more competition. To meet the increased demand for product, Vitagraph needed to strengthen its hand in film production. In August 1905, the company began building the new studio.

In September, Vitagraph's first release under its more autonomous status was Raffles the Amateur Cracksman. Exploiting its previously developed network of exhibition sites, the film was immediately shown in "Hammerstein's Victoria, Pastor's, Colonial, Alhambra, Orpheum and Gotham, Chase's (Washington, D.C.), Atlantic City Steeplechase and Arcade (Toledo, Ohio) and other houses." 20 To better market its product, Vitagraph set up distribution offices. By February 1907, it had engaged selling agents in San Francisco for the Pacific Coast (Miles Brothers) and in Chicago (Kleine Optical Co.) and had its own offices, not only in New York and Chicago, but also in London and Paris. By October 1907, Ambrosio Film was releasing several Vitagraph films, including The Haunted Hotel. in Italy. ${ }^{21}$
The Vitagraph founders combined the opening of the Paris office with an aggressive marketing scheme for The Haunted Hotel (February 1907). At a time when "French films were still announced only by title, genre and length," "Vitagraph launched the film with a flourish of hyperbolic advertising" (Crafton 1982:16). By creating fascination with the mystery of how the trick effects were achieved, Vitagraph generated an audience for its product and consolidated its position as a leading American film producer in Europe.

Communication between the New York and Paris offices gave Vitagraph an advantage in determining the kinds of films to produce and where to exhibit them. For example, by observing the lighting effects in Italian films shown in Paris, ${ }^{22}$ Vitagraph was able to anticipate the use of such techniques when making its own films. Also, Vitagraph could decide more effectively how best to exploit its films in Europe and could anticipate problems, such as the need to avoid sending films with "murders, burglaries, thefts, or anything demoralizing" to Germany because of censor restrictions. ${ }^{23}$

Vitagraph announced the opening of a factory near its sales office in Paris, not to produce new films, but to print from Vitagraph's American negatives. ${ }^{24}$ Ostensibly to avoid a three-week delay in waiting for prints to arrive from America, this strategic move thwarted efforts by other companies to imitate Vitagraph's films before they were released in foreign markets. It also increased European sales. "There are in Paris a large number of negatives which have been used in New York and are now to be printed [for] European sales." 25 During the nickelodeon era, I believe Biograph lacked its own Paris office. Vitagraphs were more popular in France than Biographs in part because the Vitagraph Company was in a much stronger position to promote its own product. In March 1913, Vitagraph was releasing more footage per month $(1,060$ meters in Paris) than each of the eleven other American film companies whose films were also exhibited in Paris. ${ }^{26}$

\section{Film Genres}

What kinds of films was Vitagraph making that were so popular? Like other film producers around the turn of the century, Blackton and Albert E. Smith made both one-shot trick and mischief films and actualities. ${ }^{27}$ Typical of the style of the period, The Burglar on the Roof (1898), shot on the roof of the Morse building, shows a thief who is beaten with brooms by several women. The film is photographed against a flat background containing painted backdrops and at a subject-to-camera distance revealing floorboards in 
the foreground. In 1900 Blackton and Smith went to Galveston and photographed eight films of the aftermath of the hurricane and floods, ${ }^{28}$ including Panorama of East Galveston; Bird's Eye View of Dock Front, Galveston; and Panoramic View of Tremont Hotel, Galveston. These films are striking to watch, although the scenes are photographed in typical fashion for actualities of the period. The images show incredible devastation and ruin over a desolate landscape through slow panning to the right and left. Some pans continue for as much as 180 degrees, and all end at random points.

During this early period, Vitagraph also duplicated and exhibited films of other competitors. Vitagraph's Bulletin from 1903 to 1904 offered diverse genres of films, including spectacles and fairytales such as Alladin and the Lamp of the Genii and The Passion Play, travel and actuality subjects like Cairo and the Ancient Pyramids and Queen Victoria's Funeral, and dramas and comedies including East Lynne and Foxy Grandpa. Lacking its own large studio to meet the demand for films, Vitagraph imported foreign productions such as Lumière's Passion Play and "The Life of Napoleon, Vitagraphically shown for the first time in America." 29

From 1905 to 1907, with acreage and a studio in Brooklyn in which to make films, Vitagraph produced and advertised its own product almost entirely. It continued to offer a diverse fare, and the trade papers indicated that "the variety of subjects pleases the audiences greatly." ${ }^{30}$ By 1907, the rise of the nickelodeon had produced a significant shift in the kinds of films that were made, away from actualities and toward narrative dramas. Vitagraph's production pattern anticipated this change (Vitagraph in addition made and marketed trick films for a longer period of time than many other American companies, probably to compete more effectively with the French companies in the European market). In comparison to Biograph, at least, Vitagraph made fewer actualities while producing more noncomic dramas. For example,

Biograph's actuality production was about one-third of its output in 1905 and almost half of its output in 1906, while only 5 percent of Vitagraph's films released from the fall of 1905 to the end of 1907 were actualities. ${ }^{31}$

Although "by far the largest number of [films in 1907] were comedies" (Bowser 1983), they comprised only a bit more than half of Vitagraph's oeuvre during that year. In 1907, Biograph made only three noncomic dramas (10 percent of its yearly output), whereas Vitagraph made twenty-nine, or 41 percent of the annual production. The following study of the surviving Vitagraph films contrasts the different ways in which the company was handling the means of expression for each genre.

\section{Actualities}

The new studio enabled Vitagraph to concentrate on the internal production of films without having to rely on external events. Vitagraph released only seven actuality films from September 1905 to December 1907. These were: the annual Vanderbilt auto races (October 1905 and 1906), a travel special for Hale's Tours (June 1906), an Elk's convention in Philadelphia (July 1907), appearances of politicians (a naval review by President Roosevelt [September 1906] and a visit to the Battery by William Jennings Bryan [September 1906]), and scenes from the San Francisco earthquake (May 1906). None of these films survived, so they cannot be studied in detail and compared with the style of other actuality films.

The release of these films reveals much about Vitagraph's aggressive publicity schemes and is consistent with its hyperbolic advertising of The Haunted Hotel in Paris (see above, page 9). Vitagraph's publicity stressed the company's ability to take privileged views of the action. The Great Naval Review at Oyster Bay contained "a splendid series of views obtained through special permission of the naval authorities," ${ }^{12}$ and the scenes of William Jennings Bryan were made in "an intimate close range portrait." 33 Vitagraph reported that

Our special photographer who was in the Far West at the time of the great disaster at San Francisco, wires us that he has secured a marvelous series of pictures of this terrible event. ... Absolutely genuine, clear, sharp, and distinct. ... We didn't "fake" it. We didn't get there several weeks after. We didn't "spoil our negatives." 34

There is no evidence that Vitagraph employees traveled much outside New York City in order to make films during the entire 1905-1907 period. More likely, Vitagraph showed the authentic record of the disaster which was filmed by Harry Miles, because six months thereafter, distribution of Vitagraph films in the West was handled by the Miles Bros. exchange. ${ }^{35}$

Vitagraph filmmakers were more concerned with weaving documentary footage into their narratives when making dramas out of doors than in making actuality films. The 100 to 1 Shot or, a Run of Luck (August 1906) is the story of a young man who saves his sweetheart's family from foreclosure on its farm by winning money at the horse races. He is shown at the actual location of the races, his actions integrated into authentic backgrounds of the betting window, racetrack, stands, and lawns. A Race for a Wife! (October 1906 ) is an adventure film incorporating scenes from the Vanderbilt auto race in which "a pretty American girl promises to marry her sweetheart if he wins the Cup Race." ${ }^{66}$ Like Chaplin's Kids Auto Races at Venice (1914), the fictional story was composed around the actual event. The release of Vitagraph's 
actuality film The Vanderbilt Cup Race (October 1906) was promoted in contrast to its dramatic fiction film: "None of the above scenes shown in the 'Race for a Wife' are included in the straight racing pictures." 37 During the nickelodeon era, the taking of actualities at Vitagraph appears to have been influenced primarily by what newsworthy items were happening nearby the studio and offices rather than the expression of an ongoing commitment to this form of filmmaking. Yet even when a given genre of filmmaking was not the mainstay of Vitagraph's output, the company was adept at creating interest in the films being seen.

\section{Comedy Chases}

Chase films were very popular by the beginning of the nickelodeon era. They inherited the model of action from actuality filmmaking of earlier years. In order to exploit depth in exterior shooting, characters traverse the image, moving from the background toward the foreground, diagonally across the field of vision. Examples of this kind of movement in actuality production occur in Lumière films such as The Photography Congress at Lyon (1895) and in a series of films recreating the Boer War made by Edison in 1900. In a similar manner in the multiple-shot chase films, the characters run diagonally from the background to the foreground. The characters traverse manmade and natural obstacles in their paths such as fences, bodies of water, and steep inclines. A cut occurs after all the characters leave the frame.

The chase film format shifted during the nickelodeon era. The protagonist became more prominent, manipulating the actions of his pursuers. More narrative variety was introduced into the films. For example, in Vitagraph's The Jail Bird and How He "Flew," the convict dresses himself as a scarecrow as the authorities pass him by; later he tricks a man into sitting on a bench with wet paint, and when the man stands up, he gains the convict's stripes, and the police chase after him.

Four Vitagraph chase films from this period survive: The Green Goods Men (January 1906), The Jail Bird and How He "Flew" (July 1906), "And the Villain Still Pursued Her;" or, the Author's Dream (December 1906), and The Stolen Pig (May 1907). In these films, Vitagraph varied greatly the direction of movement in the separate chase shots, using more fully the foreground and background, and the edges and the middle spaces of the frame. Characters frequently move against walls in exteriors instead of through open spaces.

In shot 9 of The Green Goods Men, the chased man arcs from the right rear into the center of the image, then hides off to the right midground in a door- way while the pursuers run by him toward the foreground, close to the camera. He then arcs out and back around to the left of the frame, then back the way he came, and the others give pursuit from the left center of the image toward the right rearground. In shot 4 of The Stolen Pig, the man runs parallel to the wall of the building behind him, which is at a diagonal to the axial plane. In this way, the viewer's eye is drawn on the diagonal toward the center of the image. In contemporary Vitagraph noncomic dramas photographed in interiors, such as Foul Play or, a False Friend (January 1907), this kind of centering was more fully exploited in interior spaces as well.

An inventive variation in the chase film genre was Vitagraph's construction of the chase along vertical rather than horizontal lines. The Green Goods Men contains part of the chase up a fire escape, over roofs, and down a chimney into the police station. "And the Villain Still Pursued Her," made after completion of the new studio, contains a chase that moves through the interior of a building, up stairs, onto the roof, and into a hot-air balloon in the sky, until the protagonists let go and fall back to earth, the artist crashing into his garret and awakening from the dream.

In these comedy chases, the variations in movement further broke up the diagonal line of action present in the prototypical chases. Although the space of the frame was more fully utilized, a lessclear articulation of the temporal and spatial relationship between one shot and the next resulted. Only when Vitagraph began linking shots in dramatic narratives did these juxtapositions become more clearly defined.

\section{Irick Films}

Blackton's precinematic career was as a cartoonist and Smith's as a magician, so both were interested in exploring the uses of animation and trick effects in films. In early cinema, as Eileen Bowser observed in "Preparation for Brighton-The American Contribution," "Trick films were popular at first, up to the end of 1903" (National Film Archives 1982:6) and most frequently involved the stop-action substitutions made famous by Méliès. They also utilized dissolves and double exposures, cutouts and wires, and accelerated/slow motion by under/overcranking the camera. After the new studio was built in 1905-1906,

Vitagraph continued to produce trick films into the nickelodeon era.

Vitagraph's first trick films in this period were profilmic, involving the creation or resolution of plots pivoting around trick furniture, such as "The escape of Raffles through a trick cupboard" 38 in Raffles the Amateur Cracksman. In The Green Goods Men, a 
bag containing the life savings of a country couple is switched with another bag by the confidence men through a false bottom in a trick table.

In stop-motion substitution films, a person, animal, or object is shown, the camera is stopped, and a substitution is made. When the film is projected continuously, it gives the impression of transmutation. Vitagraph advanced this effect through the technique of object animation. In this process, inanimate objects are slightly moved with each revolution of the crank of the camera. These single-frame exposures create the illusion of the independent movement of objects without having to resort to wires or cables and without the intervention in the image of live protagonists. The release of The Haunted Hotel in Paris made this technique, "Le Mouvement Américain," famous (Sadoul 1951:65; Crafton 1982:16). In this film, many animations occur. In one sequence,

\begin{abstract}
The traveler enters and is terror stricken at the weird incidents that follow. After many frights he finally seats himself at a table and to his surprise the dishes are placed and shifted by invisible hands. A large knife mysteriously raises itself in the air and slowly cuts slice after slice from a large bologna. The napkin then unfolds itself and wipes the blade of the knife. A demijohn walks around the table to a wine glass and the wine is poured out. The knife then cuts slices of bread from a loaf, the teapot steams and pours tea out into the cup. Phantom sugar tongs drop lumps of sugar into the tea, and then the milk pitcher tries hard to pour out milk but fails. ${ }^{39}$
\end{abstract}

The Haunted Hotel was not the only film to use object animation. At about the same time, Edison made The Teddy Bears (February 1907), and Biograph released A Tired Tailor's Dream (August 1907). Two months earlier than The Haunted Hotel, Vitagraph released A Midwinter Night's Dream or Little Joe's Luck (December 1906), which also contained an object animation sequence. A child's stuffed animals and his wooden toys perform elaborate movements, including one clown climbing a miniature ladder. What made The Haunted Hotel, and not A Midwinter Night's Dream, such an influential film, however, was the coinciding of its release with the opening of

Vitagraph's Paris office.

Vitagraph, capitalizing on the success of The Haunted Hotel, perpetuated the genre of object animation films. Other Vitagraph films, not extant, that probably used object animation include The Disintegrated Convict (September 1907), in which "Prisoner's body drops to floor in pieces -Fragments fly together and quickly become whole and sound": 40 The Kitchen Maid's Dream (November 1907), in which "In mysterious manner [tired servant's] hands become detached-Remove rug from floor and sweep room-Dishes wash themselves_-Knives and forks do likewise, and unaided, climb into knife box-Basket is woven and taken away with no apparent assistance",41 and A Crazy Quilt (November 1907), in which "Huge boots play around-Trousers move around mysteriously." 42

The Vitagraph directors also used the principle of object animation in cartoon drawings recorded on film in Humorous Phases of Funny Faces (April 1906) and Lightning Sketches (July 1907). These films show the artist (Blackton), his drawing board, and the objects and characters that undergo various movements and transformations, such as sketches of a Jewish man from the word "Cohen" and a black man from

"Coon," a dog jumping through a hoop, and a drink spritzed into a glass.

Vitagraph's object animation films were seen by numerous filmmakers, especially in Europe, including Gaumont employees Segundo de Chomón, Walter Booth, Emile Cohl, and Winsor McKay (Crafton 1982 chap. 1). Once they discovered Vitagraph's method, the technique was imitated, and improvements followed. Vitagraph's object animation films were the bridge between the stop-motion substitution films of Méliès and his contemporaries and the cartoons (animated drawing films) of later years.

Vitagraph also made imitations of object animation using different trick effects, primarily in films involving the mixup of dummies with real people. In The Thieving Hand (February 1908), a one-armed man obtains an artificial limb. The man cannot control his new arm, which steals from passersby. Stop-motion substitutions are used to interchange a dummy hand with a real one, and wires are used to pull the arm when it is detached from the rest of the body. In The Window Demonstration (July 1907), the mannequins in the window are played by real people, who imitate staccato movements of mechanical dummies.

Trick effects were associated at first with magic and in the context of characters' dreams. Around 1907, they became linked to technology. In Vitagraph films such as Work Made Easy (December 1907) and Liquid Electricity; or, the Inventor's Galvanic Fluid (September 1907), trick effects are the result of inventions. In these films, illusionism is linked with science. In Work Made Easy, "A professor of dynamics invents wonderful machine, by aid of which he performs most difficult and arduous labors by merely turning the handle and sending waves of magnetic force into objects either animate or inanimate." 43 In Liquid Electricity, through undercranking the camera, the chemist's "wonderful invigorating fluid" 44 causes streetcleaners, clerks, ditch diggers, and other laborers to become extremely active. The mise-en-scène for the laboratory is detailed and shows instruments, cables, and revolving gears as well as smoke, light, and explosion effects.

In trick films, the primary concern was the process of transforming a person or object within a scene 
rather than the manner of switching from scene to scene. An example is the object animation that occurs in A Midwinter Night's Dream. In shot 3, the children are put in bed by their mother, the action represented in full-length view. Shot 4 cuts to a closer view, showing the girls in bed. Shot 5 returns to the setup in shot 3 , and then the camera pans to the boy's side of the room. There is a cut to a closer view of the boy in bed, matching the distance established in shot 4 , in order to show that the animation of stuffed animals and wooden toys is achieved without the use of wires. In shot 6, a series of left-right camera pans occurs. When the camera pans left to remove the child from the field of vision, object animation of the stuffed animals and wooden toys occurs.

Showing objects moving in a convincing fashion without wires required a closer view of the action, however, at a time when close views were seen by filmmakers "as interruptive to the narrative rather than contributing to it" (Bowser 1983:5). Vitagraph trick films during the nickelodeon era perpetuated early methods of visual expression instead of providing the transition to a new mode of representing space and time within and across shots.

\section{Contemporary Vitagraph Dramas}

During the nickelodeon era, Vitagraph produced a wide variety of dramatic films. They involved western settings and miners (The Prospectors [June 1906] and "The Bad Man" a Tale of the West [February 1907]), the Civil War and slavery (The Spy, A Romantic Story of the Civil War [March 1907], The Slave [June 1907], and The Despatch Bearer or, through the Enemy's Lines [November 1907]), the sea (Cast Up by the Sea [September 1907] and A Tale of the Sea [December 1907]), contemporary issues involving crime, chases, and detectives (The Escape from Sing Sing [November 1905], Secret Service or, the Diamond Smuggler [August 1906], and The Automobile Thieves! [November 1906]), moral lessons about old age and youth (The Fountain of Youth [September 1907]), miserliness (Retribution or the Brand of Cain [March 1907]), and reformation (The Burglar and the Baby [November 1907]).

The company also made adaptations from literary works, openly acknowledging its sources. Raffles the Amateur Cracksman (September 1905) was based on the Raffles stories by E. W. Hornung, by special arrangement with the publisher, Mr. Kyrle Bellow and Liebler \& Co.; Sherlock Holmes or Held for Ransom (October 1905) and Monsieur Beaucaire (December 1905) were made with the cooperation of McClure, Phillips \& Co. Vitagraph's business practices could be contrasted to those of the Kalem Company, which made Ben-Hur (1907) "without consulting the author of the novel or the producers of the play and ultimately paid $\$ 25,000$ for its carelessness" (Macgowan 1965:180).

Vitagraph's trick films illustrated the method of transforming a person or object within a scene. In the Vitagraph chase comedies, successive shots were treated as distinct entities, united by a common character or theme. Three surviving contemporary Vitagraph dramas from this period, however-The 100 to 1 Shot or, a Run of Luck (August 1906), Foul Play or, a False Friend (January 1907), and The Mill Girl A Story of Factory Life (September 1907)_demonstrate the importance of shooting in the new studio in terms of composition in depth and in the emergence of parallel editing. These three contemporary Vitagraph dramas describe a movement from actuality-like exterior shooting (The 100 to 1 Shot) to full use of the interior space (Foul Play) to a smooth integration of interiors and exteriors (The Mill Girl). The 100 to 1 Shot, released before completion of the studio, contains twenty-five shots, six of them "interior" scenes, sixteen on location, and three insert shots. Foul Play is the story of a wife who proves her husband's innocence by exposing his business associate as the real thief. This film of seventeen shots is constructed entirely in the studio except for one shot in which the wife trails the thief from his house to the stock brokerage firm. The Mill Girl is the story of a female factory worker who is saved from a fire by her boyfriend after she repulses the advances of her boss. This drama of thirty-one shots (and one intertitle) is divided nearly equally between exteriors (fourteen shots) and interiors (seventeen shots). Foul Play best demonstrates in one film the ways in which new means of representing space and time were replacing earlier ones.

\section{Foul Play or, Shifting the Means of Cinematic Expression}

Foul Play is listed in Vitagraph publicity as "a story of high finance." 45 This publicity fails to indicate the visual appeal of the film. It is an especially complex narrative for early 1907, at least in the American cinema. The print is 320 feet long in $16 \mathrm{~mm}$, or 800 feet in $35 \mathrm{~mm}$, as against an original length of 875 feet. About one minute of the film is missing, which may be the original title and part of the first shot. Otherwise the film is probably complete. A brief shot description follows: 46 
1. Interior, cashier's office. Full-length view. A cashier removes money from colleague's drawer, enters safe, rushes when colleague arrives. Thief exits, colleague works.

2. Interior, stock brokerage firm. Full-length view. Thief enters.

3. Interior, stock brokerage firm. Cut in to shot of thief from waist up. Thief looks at tickertape, worried.

4. As 2, thief exits stock brokerage firm.

5. As 1, thief reenters cashier's office. Then boss enters, calls innocent colleague away from his desk.

6. Interior, boss's office. Full-length view. Boss, innocent colleague, and another employee argue about the recordkeeping books.

7. As 1, thief listening in cashier's office. Then he goes to safe, removes documents, and places them in colleague's coat. Colleague returns, discusses books with thief. Colleague leaves. Boss enters safe, discovers documents missing. Thief indicates colleague left in a hurry. Police arrive. Everyone exits.

8. Interior, home, full-length view. Innocent colleague arrives home, greets his wife and two daughters. Boss, thief, and police arrive, discover documents in husband's coat. Husband is handcuffed and taken away. Wife cries with children.

9. Interior, courtroom. Full-length view. Boss testifies, thief accuses husband. Attorneys argue. Jury returns guilty verdict. Wife faints.

10. As 8 , interior, home, but camera is positioned closer to wife with children. She resolves upon action, dresses, applies makeup, and leaves.

11. Exterior, street, full-length view. Wife moves down street, hides. Thief exits house, moves up street, wife follows.

12. As 2, interior, stock brokerage firm, full-length view. Thief checks tickertape, cheerful. Wife meets him at tickertape, he follows her out.

13. Interior, restaurant. Full-length view. Wife and thief enter restaurant. She drugs his drink, he sleeps. She steals documents from his pocket and exits. He wakes and exits.

14. Interior, hallway and thief's home. Full-length view. Thief climbs stairs, enters home, discovers documents missing from his coat.

15. As 6 , boss's office. Full-length view. Wife arrives, shows boss documents. Police arrive, everyone exits.

16. As 14, thief's domain. Full-length view. Wife climbs stairs, peers through keyhole, sees thief packing and looking behind painting into a safe where documents and money are hidden. Wife enters and police arrest thief.
17. As 6 , boss's office. Full-length view. Family reunited, boss shakes husband's hand.

This film is more tightly constructed than the comedy chases, in part because it is shot in interiors and also because of the demands of the story. The seventeen shots comprise only nine different locations, some of which are shown once, others twice, and still others, three times. By returning to an earlier location to build emotional intensity or to resolve conflict, this Vitagraph film contains the seeds of an approach that Griffith was to make so famous in his Biograph films.

\section{Composition in Depth}

The first, fifth, and seventh shots of Foul Play show the two employees at work. On the right is the thief's workspace and on the left, the husband's. To the far left is the safe. The scenes are photographed in fulllength view. The men are working with their backs to the camera, against the rear wall. A railing and gate in the midground divide the movement toward the safe in the left rearground from movement to and from the boss's office off the right foreground. This mise-en-scène exploits the depth of the interior space and sets up planes of action in the area of the frame (Figure 1). It allows a spatial logic between shots as well. In each instance, the movement of characters to particular areas of the frame motivates the cuts, whether to the boss's office in shot 6 or to exteriors screen right (the stock exchange in shot 2 and the falsely accused man's home in shot 8).

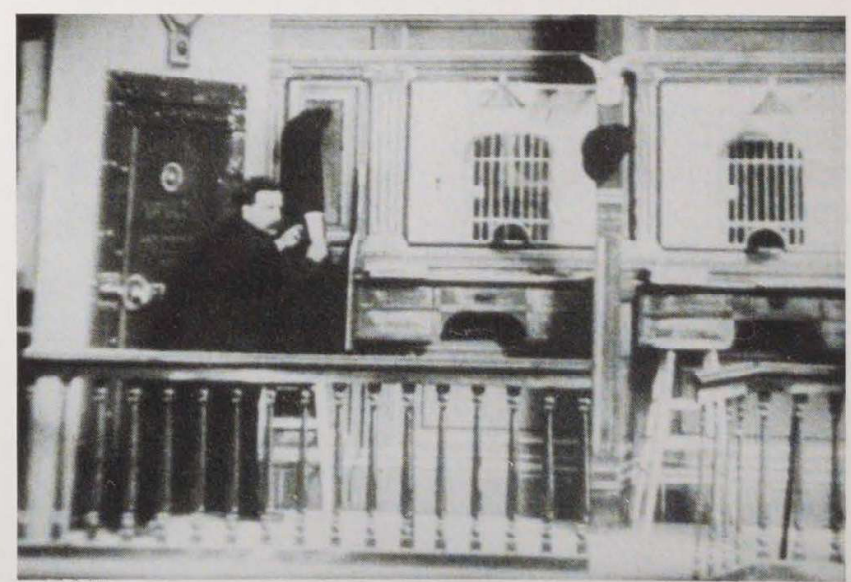

Figure 1 Thief, in office, planting documents in husband's coat (shot 7). 
A similar shot occurs in The Mill Girl, in which the female workers are weaving in the background, facing away from the camera, while the main action centers around the table in the midground. (In The 100 to 1 Shot, released before the completion of the studio, the family at the beginning of the film faces the camera. This scene lacks the complexity of planes of action evident in similar full-length shots made in the studio interior in Foul Play and The Mill Girl.)

These shots in Foul Play and in The Mill Girl also demonstrate Vitagraph's understanding of the use of staged scenes to represent a larger actuality - a part to signify the whole. In The Mill Girl, five weavers are shown against the background, representing labor An actuality film from 1904, Westinghouse Works, documents industrial working conditions. A camera records row upon row of female laborers in cramped quarters, whereas in The Mill Girl the workers are evenly spaced across the background of the frame. In Westinghouse Works, the workers are dwarfed by the tall ceilings; light seeps in through the windows, but the workers are shrouded in almost total darkness. The shots in The Mill Girl (and Foul Play) demonstrate selection from reality in order to structure the narrative and to create a fiction more dramatic than the actuality material.

This pattern of composing in depth in interiors is present throughout Foul Play. In the second shot at the stock brokerage firm, the background activity shows the workers writing against the wall at the rear of the image. Customers sit with their backs to the camera at both sides of the frame. The thief enters close to the camera in the foreground and walks down the aisle between the two groups, toward the rear (Figure 2). His exit in shot 4 brings him toward the foreground and close to the camera, and the characters' movements in the stock brokerage firm in shot 12 repeat the pattern established in these earlier shots. This composition and movement in interiors control the path of observation of the viewer down the center of the image toward the rearground, a change in concept from earlier films wherein "the significant action may take place at the side of the frame, with so many other actions going on in other parts of the frame as to make it difficult for the modern spectator to 'read' the scene" (Bowser 1983:5).

In The 100 to 1 Shot, control over the mise-enscène is greatly compromised because it is dictated by external shooting conditions. Many of the exterior shots contain actuality backgrounds. For example, shot 3 shows the boyfriend at Grand Central Station. To thrust himself into the viewer's consciousness, he walks from the background to the center foreground of the image and turns his back to the camera in order to show the audience the newspaper headline. In contrast, the viewer's eye in Foul Play is more carefully led to the significant action.

\section{Centering}

Other shots in Foul Play contain more subtle centering strategies. Much of the actuality filmmaking and comedy chases of earlier years was constructed around movement across the diagonal of the frame. Cinematic conventions led the viewer's eye from the background of the image, through its center, toward the foreground. Such a diagonal movement pervades numerous outdoor scenes of The 100 to 1 Shot. But in interior scenes of the latter film, action was played still largely parallel to the flat background

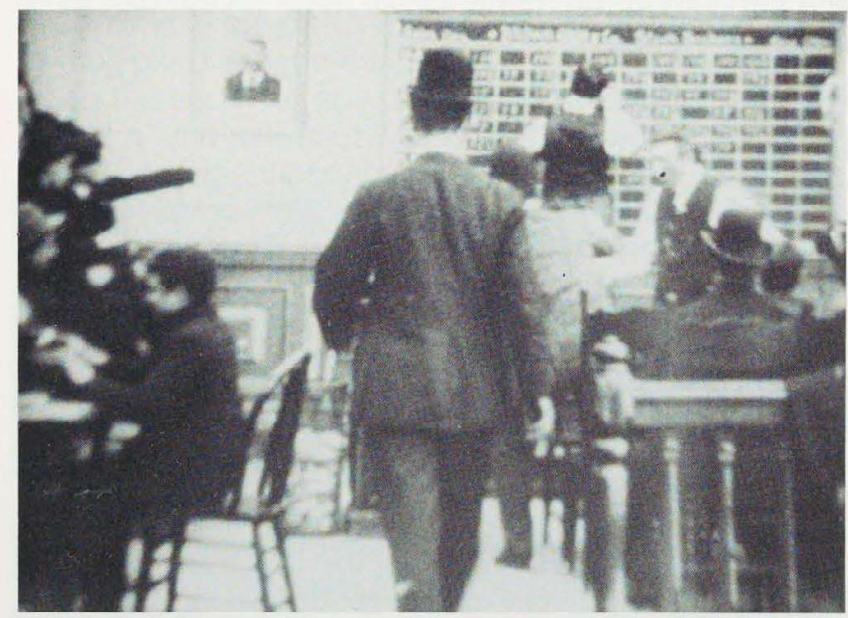

Figure 2 Thief enters the stock brokerage firm (shot 2).

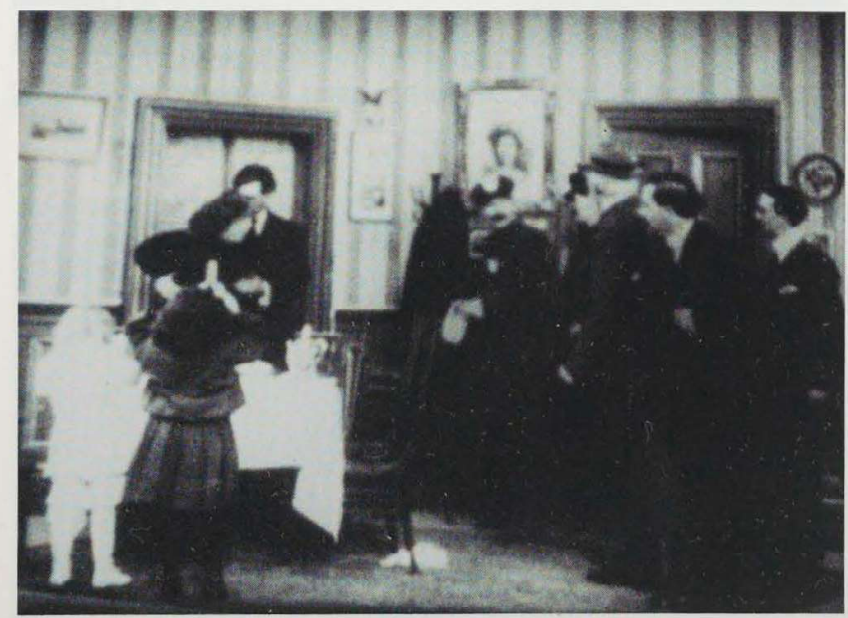

Figure 3 Boss, thief, and police arrive in husband's home and find documents (shot 8). 
In Foul Play, shots 8 and 10 are in the husband's home, and shot 9 is in the courtroom (Figures 3, 4, 5). These three successive shots are photographed not against a flat background, but instead against two corners of the room that converge in the middle rear of the image, in front of which transpires the significant action. This makes possible a greater sense of depth in the image. In the courtroom scene, multiple planes of action make full use of the interior space: the judge, witness stand, and jury in the background; the lawyers and table in the midground area; and the wife and banister in the foreground space. The camera, placed at an oblique angle, exploits the perception of a receding space. The careful positioning of the furniture in the frame allows more characters to face the camera.

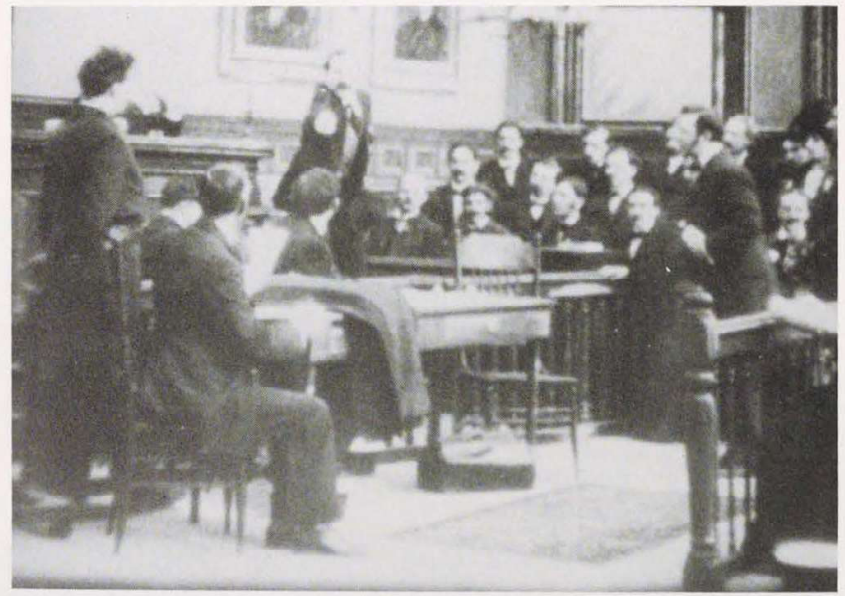

Figure 4 Thief falsely accuses husband in courtroom (shot 9).

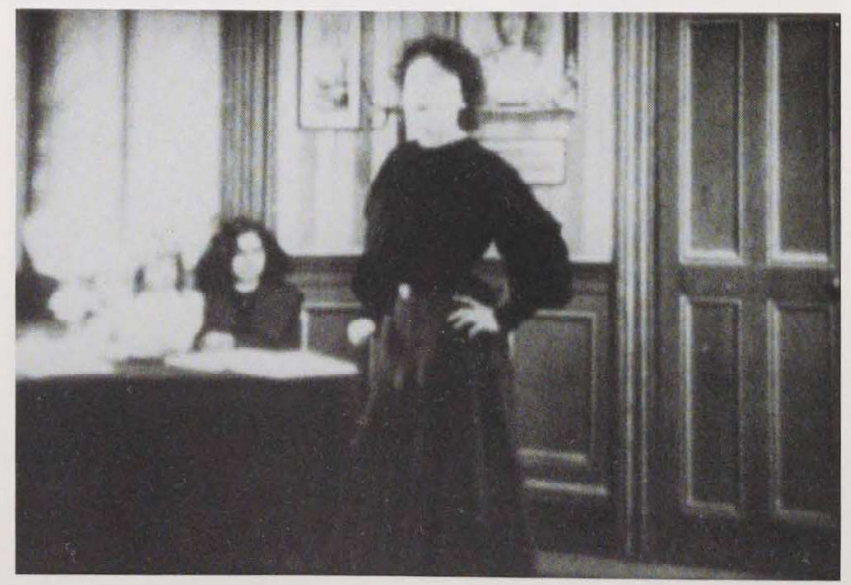

Figure 5 Wife, at home, resolves to take action (shot 10).
In Griffith's What Shall We Do with Our Old? (February 1911), the courtroom scene is photographed head on. The action is centered around the judge. He faces the camera, with the police standing on one side of the bench and the old man on the other. Major characters are shown from the side or the back, so that much of the significant action of the man's plea is lost to the viewer. ${ }^{47}$

In the courtroom shot in Foul Play, use of space is geared toward the clear presentation of the drama. This combination of visual strategies-background receding into a corner, oblique camera angle, multiplanar areas, and careful positioning of the furnitureskillfully draws the viewer's eye into the heart of the drama at the center of the image where the protagonists interact most fully with each other. This approach is evidence of Vitagraph's attempt to create a more flowing narrative by relying on centering strategies instead of interrupting the action by resorting to a direct cut-in to a close view. This attempt had succeeded by the time of The Mill Girl, in part by establishing a pattern of bringing the camera a bit closer to the action "as the narrative advances to its climactic stages" (Bowser 1983:5).

The similarity of backgrounds in shots 8,9 , and 10 of Foul Play also binds the scenes together dramatically. Like Griffith's films, which are structured around the threat of disintegration of the family structure, so too do these shots emphasize that tension. In shot 8 , the husband returns home to his family. The camera is placed at a full-length view and records the arrival of the police to arrest the falsely accused man. At the end of shot 9 in the courtroom, the wife faints in the center mid-foreground of the image. Then there is a cut back to the home. The camera is placed in the same relationship to the background as in shot 8 but is positioned closer to the protagonists. The courtroom shot divides the film's drama (and number of shots) in half. Like many Griffith films, it also shifts the resolution of the drama to the resourcefulness of the female. In the preceding shots, the husband supported the family integrity and unity. An outside force (the thief) threatens the idyll. In the courtroom, the husband's guilty sentence causes the wife to collapse. From this moment on, she moves from inaction to action and is the catalyst for resolving the drama in the remaining shots. The cut-in to shot 10 is significant in that it is separated from the earlier shot at home by the courtroom scene, thereby modifying the earlier filmmaking style of moving into closer views in a direct cut.

Direct cut-ins to closeups, however, occur elsewhere in Foul Play. In shot 2, the thief enters the stock brokerage firm. In order to show the action more clearly, shot 3 is a close view of the thief (Figure 6). Similarly, Vitagraph's The 100 to 1 Shot also contains several cut-ins to a closer view. Insert shots 


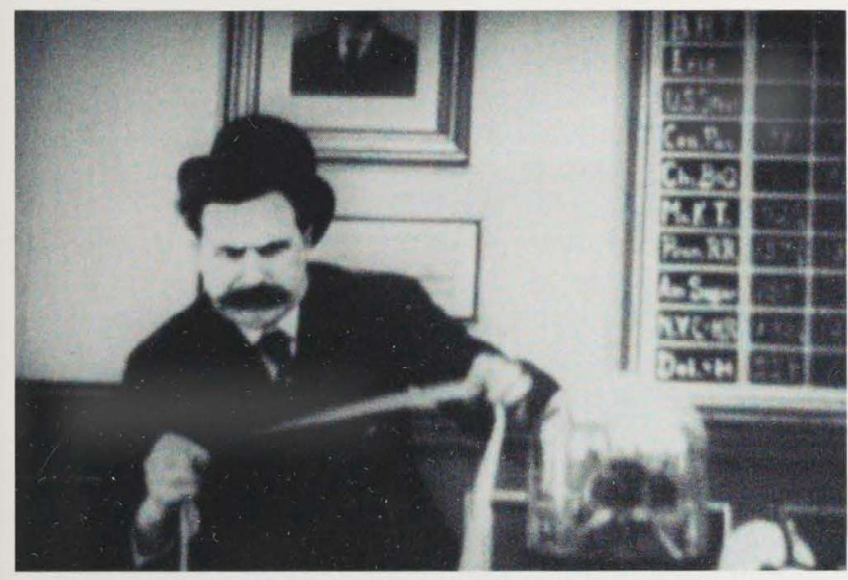

Figure 6 Thief checking tickertape at stock brokerage firm (shot 3).

show a card listing the racing odds and a telegram indicating the horse on which to bet. These close-ups are necessary to establish the ensuing action. The opening of The 100 to 1 Shot depicts a hand clutching money. Like numerous films in the prenickelodeon era, this shot functions as an allegorical tableau outside the flow of the narrative.

In Foul Play, the cut-in to a closer view in shot 10 functions differently. First of all, suspense about the effect of the husband's arrest on home life is drawn across several shots. Shot 10 also works as the inverse of the wife's collapse in the preceding shot in the courtroom; in shot 10 she resolves to action. And, because of the restrained acting, the closer placement of the camera brings the viewer into the wife's emotional reactions. Her thought processes are projected. She gestures her hand and places her fingers on her mouth, not knowing what to do.

Momentarily she stops. Her eyes move and reveal her resolving upon a decision.

In Griffith's Brutality (December 1912), a husband and wife attend the performance of a play, and the camera cuts between showing the couple in the audience and the action on the stage in full-length view. At the moment when the husband identifies with the drama emotionally, Griffith cuts to a closer view of the action on the stage, showing the actors from the waist up. Although the editing in Foul Play lacks the backand-forth cutting strategy of Brutality, which shifts to the protagonist's point of view, it is an earlier example of moving the camera closer to involve the spectator more intimately in the reactions of the characters.

\section{Simultaneous Action}

Making films in the new Vitagraph studio made more composition in depth in interiors possible, but at the same time it posed new problems in representing simultaneous action in contiguous spaces. In Foul Play, Vitagraph employed conflicting strategies to establish temporally parallel events: through staging within the mise-en-scène and through separate shots. The staging methods used to establish temporally parallel actions were indebted to earlier filmmaking styles and still earlier theatrical traditions, while the technique of showing simultaneous action in separate shots anticipated the newly emerging form of parallel editing.

Using staging techniques inherited from the theater, ${ }^{48}$ filmmakers denoted simultaneity through the use of multiple playing areas within the frame, especially when the separate spaces were delineated by the use of a split set. Shot 7 of Foul Play shows in fulllength view the work space of the two employees. On the right is the thief's area and on the left, the husband's. To the far left, after characters pass through the safe's door, action is shown within the space of the safe. This space within the safe is ambiguously represented. We can view the characters in the safe both through the area of the office and from just behind the wall separating the safe from the office (Figure 7). Is this area within the safe to be understood as part of the space of the employees' room, as a cutaway set, or as careless framing in making the film?

In shot 16, the wife climbs up the stairs with the police, peers through a keyhole, and observes the thief in his apartment. The stairs are on the right, the door is in the center of the image, perpendicular to the flat background, and the thief's room is on the left. As the

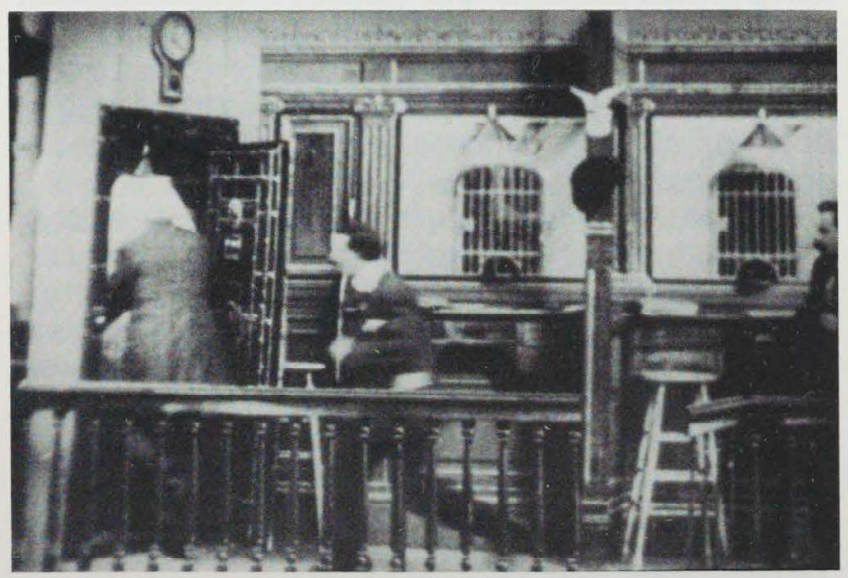

Figure 7 Boss enters safe, discovers documents missing (shot 7). 
wife kneels down to look through the keyhole, the camera pans and shows more of the man's room. He is packing his bags and reveals his document hiding place to be in a safe behind a picture on the wall. Two simultaneous actions - the wife peering through the keyhole and the man packing his bags - are shown in the same shot (Figure 8).

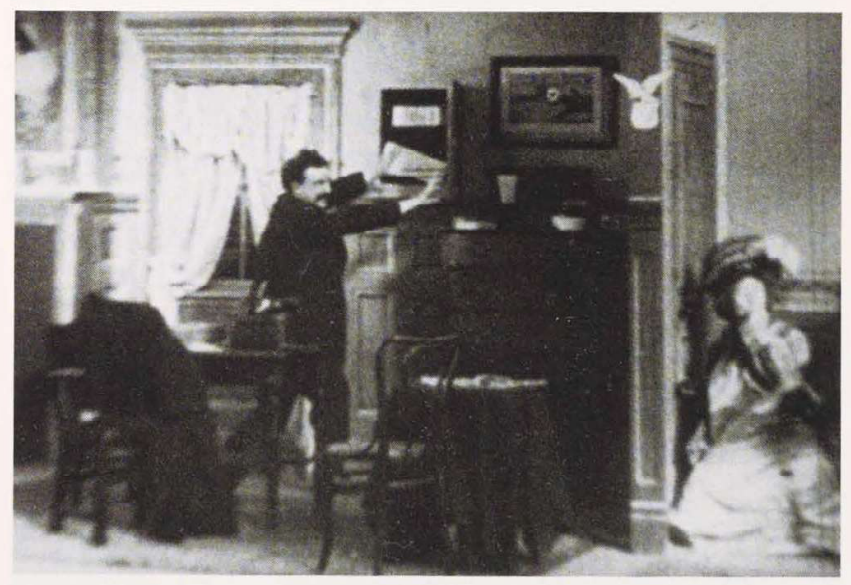

Figure 8 Wife peers through keyhole and sees thief looking in safe at his home (shot 16).

In the immediately preceding Vitagraph release, A Midwinter Night's Dream (December 1906), this panning strategy also occurs. In shot 2, a camera pan takes place from the family gathered around the dinner table, across a door perpendicular to the flat background, to the adjacent living room. This camera movement leads to another line of action, that of the children opening presents. As the camera pans, the father leaves the table and crosses through the door. $\mathrm{He}$ dresses as Santa and climbs up the fireplace. As the camera pans further to show the Christmas tree, the children and the female adults pass through the door and arrive in the living room as the father descends as Santa.

Camera movement occurs with regularity in exterior shooting during this period but is extremely unusual for interior shooting ${ }^{49}$ Because of the larger playing area within the new studio, Vitagraph was also able to pan in interior studio shooting in order to link simultaneous actions in adjacent spaces in both A Midwinter Night's Dream and Foul Play.

Showing simultaneous action in separate shots is firmly established in shots 14 and 15 of Foul Play, although it is not as fully developed as the classic $A B A B$ pattern of parallel editing of later years. After the wife resolves upon action in shot 10 , she leaves her house. In shot 11, an exterior, she trails the thief.
He enters the brokerage firm (shot 12), where she allows him to meet her, and in the next shot (13) they enter a restaurant. She drugs his drink (Figure 9), steals the documents from his pocket, and exits. He wakes up, realizes she has left, and also leaves. In the next shot (14) the thief arrives home (Figure 10). As the thief discovers the documents missing, the wife goes for help at the boss's office. Although the wife had left the restaurant before the thief, we only now return to her actions. In shot 15, she enters the boss's office and shows him the stolen documents (Figure 11). The action across the edits from the restaurant to the thief's house and then to the boss's office sets up a clear instance of two actions occurring simultaneously in successive shots. In contrast to the point of view that the early instances of parallel editing are across adjacent spaces (Bowser 1983:11), this editing pattern occurs across distant ones. The sequence of shots 13 through 16 of the wife's producing evidence to arrest the thief contains an extraordinary collision between the early means of expression and the new - representing simultaneous action within the same shot on the one hand, and in successive shots on the other.

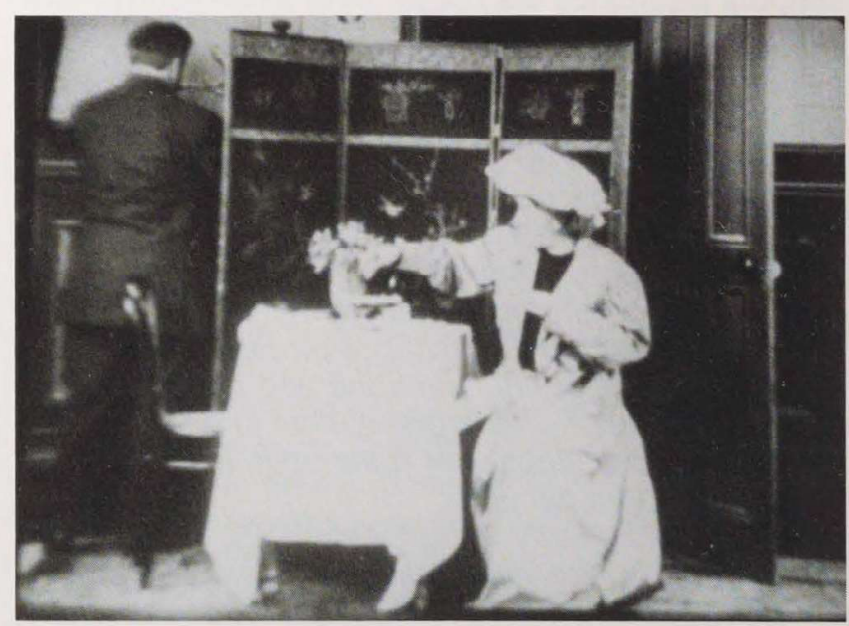

Figure 9 Wife drugs thief's drink in restaurant (shot 13).

\section{Vitagraph Forged Ahead}

By the end of 1907, Vitagraph was in the forefront of composing sophisticated contemporary dramas. Making dramas in the new studio had challenged Vitagraph to find new ways of representing space and time in a continuous narrative flow. Vitagraph was meeting the demands of more complex narratives by integrating composition in depth with simultaneous action in successive shots. 


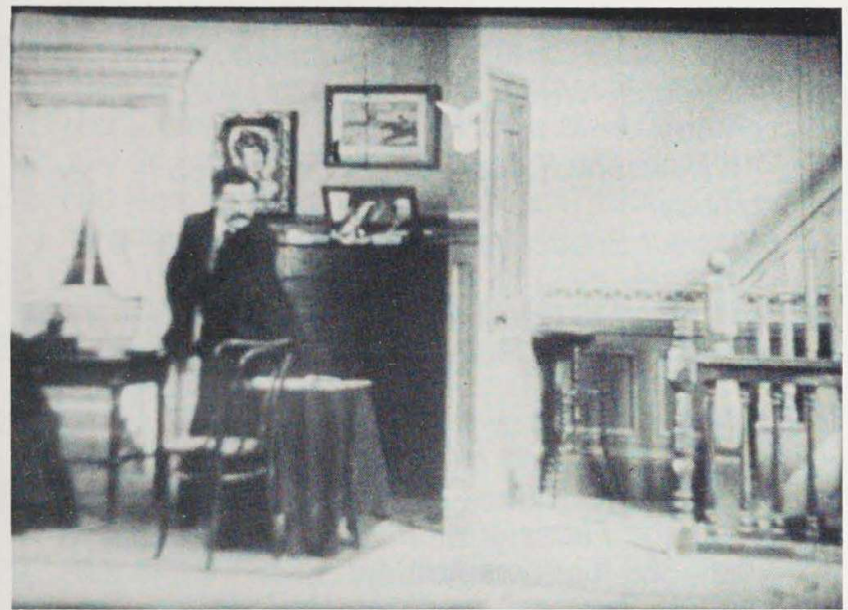

Figure 10 Thief discovers documents missing from his coat (shot 14).

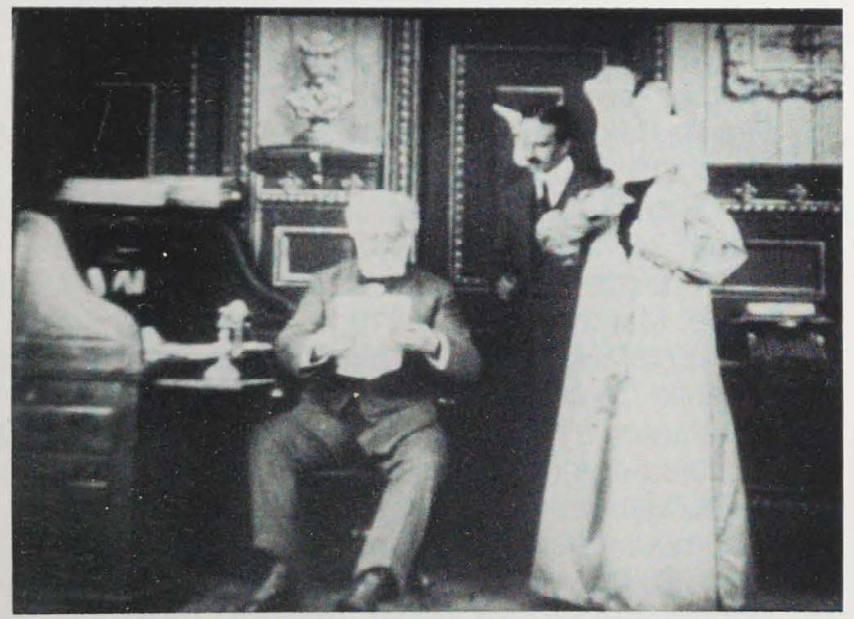

Figure 11 Wife arrives and shows boss documents (shot 15).

The 100 to 1 Shot or, a Run of Luck was made just before completion of the studio. It contains a good integration of actuality-like exterior action recorded across the diagonal of the frame but at the same time continues early means of representing action played against flat backgrounds in "interiors." While a temporal linear narrative progresses in successive shots throughout most of the film, simultaneous action in successive shots is incorporated at the end of the film. In shot 21, the boyfriend, having won money at the races, hires a car to return home. The vehicle moves away from the camera. In shot 22 , in a reverse angle (but in a different location), the car careens down the road toward the camera. Shot 23 returns to the camera setup in the second shot of the film, with the family about to be evicted from its home. In shot 24 , the car pulls up in front of the house. The boyfriend enters the home in shot 25 just in time to save the family.

Foul Play or, a False Friend, made several months after completion of the studio, is significant for centering the action, composing in depth, and articulating temporal simultaneity in successive shots. By the time of The Mill Girl-A Story of Factory Life nine months later, composition in depth and parallel editing were fully integrated into exterior and interior filming.

In The Mill Girl, the smooth flow of action across shots suggests patterns of simultaneity over the entire film rather than over only a few shots. The scenes of the boss hiring thugs in a dive and readying them for ambush near the beginning of the film (shots 7 and 8) are embedded within similar shots of the lovers outside the gate of the girl's home in shots 6 and 9. Near the end of The Mill Girl, shots 28 of the boss escaping down stairs in the interior and 29 of the boyfriend climbing up the building in an exterior are embedded within similar shots of the girlfriend being overcome by fumes in shots 27 and 30 .

By the end of 1907, interior/exterior cutting was becoming an established convention-a change from the earlier practice of showing all the exterior action and then the interior action, as in The Life of an American Fireman (1902). In the middle of The Mill Girl is a nine-shot editing pattern (shots 11-19) that contrasts the boyfriend in his bedroom with the thieves climbing up outside his window. Immediately thereafter, shots 21-27 cut back and forth between the mill worker's space and the boss's office. The sequence begins with the boyfriend describing to the mill girl his beating up the thugs, thereby linking this simultaneous-action sequence with the prior one. In this latter simultaneous-action sequence, while the employees work, the boss fires the boyfriend and makes advances upon the heroine.

In these contemporary dramas, Vitagraph developed temporal simultaneity into an $A B A B$ editing pattern. In later years, Griffith would exploit more complex montage strategies, at least at the level of permuting $A B C$ patterns, in his cutting between the attacker, the attacked, and the rescuer. But alreadv many months before Griffith began directing at Biograph, Vitagraph had established the elements of a newer filmmaking style, as well as the studio production, distribution, and publicity methods to anticipate the rapid changes in the industry and to compete more effectively with its product in the marketplace. 


\section{Filmography}

The following is a filmography of Vitagraph releases between September 1905 and December 1907. It is the basis for the statistical comparisons with other companies that are discussed in the body of this article. The New York Clipper is the source of information for this filmography. It is the only periodical to track fully the Vitagraph releases beginning in September 1905.

Titles given are those used in the Clipper. A given title frequently varied in phrasing and punctuation when announced from week to week. In listing titles in the filmography, I have usually chosen the title for the first announcement of the film's release. Vitagraph frequently favored two-part titles, such as The Mill Girl A Story of Factory Life and Liquid Electricity; or, the Inventor's Galvanic Fluid. Dates listed are those when the Clipper advertised the films as being ready for purchase. Rarely is a precise release date given. Actual releases were within a few days of the weekly issue of the newspaper. Lengths are those supplied in the Clipper ads. Surviving prints are frequently shorter, missing one or more shots. Genres are divided into comedy, drama, and actuality. I have used my best judgment for genre when the Clipper description was unclear as to comic or dramatic. Reissues are noted as separate releases when they are so treated by Vitagraph, such as Raffles the Amateur Cracksman and The Flat Dwellers.

Also listed are places where copies are available, according to the following code: MOMA (The Museum of Modern Art), LOC (The Library of Congress), GEH (International Museum of Photography at George Eastman House), and NFA (National Film Archive, London). Where no notation is included, the film is not known to exist. Incomplete paper prints in the process of being copied are not included in these designations.

\section{Releases}

1. Raffles the Amateur Cracksman, September 23, 1905, 1,050 ft., drama.

2. The Servant Girl Problem, September 30, 1905, $800 \mathrm{ft}$., comedy.

3. License No. 13, or the Hoodoo Automobile, October 7, 1905, $750 \mathrm{ft}$., comedy.

4. Sherlock Holmes or Held for Ransom, October 7, 1905, 725 ft., drama.

5. Vanderbilt Auto Race, October 21, 1905, 200-, 300-, 400-, or 500-foot lengths, actuality.

6. Black and White, October 28, 1905, $470 \mathrm{ft}$., comedy.

7. The Escape from Sing Sing, November 4, 1905, 775 ft., drama.

8. Burglar Bill, November 18, 1905, $210 \mathrm{ft}$., comedy

Filmography research copyright (c) Jon Gartenberg, 1983.
9. Moving Day or, No Children Allowed, November 25, 1905, $790 \mathrm{ft}$., comedy

10. Oh! You Dirty Boy!, December 2, 1905, $90 \mathrm{ft}$., comedy.

11. The Newsboy, December 23, 1905, $785 \mathrm{ft}$, comedy.

12. Monsieur Beaucaire, December 23, 1905, 615 $\mathrm{ft}$., drama.

13. Man Wanted, December 30, 1905, $300 \mathrm{ft}$., comedy.

\section{Releases}

1. The Green Goods Men, January 6, 1906, 730 $\mathrm{ft}$., comedy, LOC.

2. Flags and Faces of All Races, January 13, 1906, $365 \mathrm{ft}$., comedy.

3. Post No Bills or, Advertising Up-to-Date, January 27, 1906, 485 ft., comedy.

4. The Flat Dwellers, February 3, 1906, $450 \mathrm{ft}$, comedy

5. The Man with the Ladder and the Hose, February 17, 1906, $475 \mathrm{ft}$., drama.

6. The Modern Oliver Twist or, the Life of a Pickpocket, March 3, 1906, 800 ft., drama.

7. Please Help the Blind or a Game of Graft, March 10, 1906, $475 \mathrm{ft}$., comedy.

8. The Lost Collar Button or, a Strenuous Search, March 24, 1906, $430 \mathrm{ft}$., comedy.

9. A Strenuous Wedding, or Matrimony a la Mode, March 31, 1906, $410 \mathrm{ft}$., comedy.

10. Stop Thief, March 31, 1906, 277 ft., comedy.

11. Juvenile Chicken Thieves, March 31, 1906, $220 \mathrm{ft}$., comedy.

12. Troubles of a Hobo, or No Rest for Weary Willie, March 31, 1906, 245 ft., comedy.

13. Humerous Phases of Funny Faces, April 7 , 1906, $230 \mathrm{ft}$., comedy, LOC, NFA.

14. Nobody Works Like Father, April 14, 1906 , $690 \mathrm{ft}$., comedy.

15. Oh! That Limburger!, April 28, 1906, $600 \mathrm{ft}$, comedy.

16. The San Francisco Earthquake!, May 5 (ca $800 \mathrm{ft}$, 4 items); May 12 (ca. 1,200 ft., 6 items); May 19 (ca. 1,500 ft., 8 items), actuality.

17. Raffles - The Amateur Cracksman, May 5, $1906,1,070 \mathrm{ft}$., drama. Note: This is a rerelease of a 1905 film, because of "the great demand for this film in shorter lengths"; reissued in 2 parts, 20 feet longer than the original release.

18. Love versus Title or, an Up-to-Date Elopement, May 26, 1906, $720 \mathrm{ft}$., drama.

19. The Prospectors, June 9, 1906, $770 \mathrm{ft}$., drama

20. Special! For Hale's Tours, June 9, 1906, 800 ft. (sold in 200-, 400-, 600-, and 800-foot lengths), actuality.

21. All Aboard! Or Funny Episodes in a Street 
Car, June 23, 1906, 485 ft., comedy

22. The Jail Bird and How He "Flew," July 7 , 1906, $610 \mathrm{ft}$., comedy, LOC, NFA.

23. The Snap-Shot Fiend, or Willie's New Camera, July 21, 1906, $610 \mathrm{ft}$., comedy.

24. The Acrobatic Burglars, August 4, 1906, 660 ft., comedy.

25. The 100 to 1 Shot or, a Run of Luck, August 11, 1906, 640 ft., dramä, MOMA, LOC, GEH.

26. The Hand of the Artist, August 11, 1906, 200 $\mathrm{ft}$., comedy.

27. Funny Fish and Their Captors, August 11, 1906, $200 \mathrm{ft}$., comedy.

28. Secret Service or, the Diamond Smuggler, August 25, 1906, $655 \mathrm{ft}$., drama.

29. Pals or My Friend, the Dummy, September 8 , 1906, $670 \mathrm{ft}$., comedy.

30. William Jennings Bryan, September 8, 1906, $150 \mathrm{ft}$., actuality.

31. Great Naval Review at Oyster Bay, September 8, 1906, $500 \mathrm{ft}$., actuality.

32. The Indian's Revenge; or, Osceola, the Last of the Seminoles, September 22, 1906, $795 \mathrm{ft}$., drama.

33. A Race for a Wife!, October 13, 1906, $850 \mathrm{ft}$., drama.

34. The Vanderbilt Cup Race, October 13, 1906 , $500 \mathrm{ft}$., actuality.

35. Mother-in-Law, October 27, 1906, 620 ft., comedy.

36. The Automobile Thieves!, November 10, 1906, $985 \mathrm{ft}$., drama.

37. "And the Villain Still Pursued Her;" or, the Author's Dream, December 1, 1906 (ready for delivery December 5), $800 \mathrm{ft}$., comedy, GEH, NFA.

38. A Midwinter Night's Dream or Little Joe's Luck, December 15, 1906, $600 \mathrm{ft}$., drama, GEH, MOMA (excerpt).

\section{Releases}

1. Foul Play or, a False Friend, January 5, 1907, $875 \mathrm{ft}$., drama, GEH.

2. The Mechanical Statue and the Ingenious Servant, January 19, 1907, $450 \mathrm{ft}$., comedy.

3. "The Bad Man" a Tale of the West, February 2, 1907, $660 \mathrm{ft}$., drama.

4. Fun in a Fotograf Gallery, February 16, 1907, $785 \mathrm{ft}$., comedy.

5. The Haunted Hotel, February 23, 1907, $500 \mathrm{ft}$. comedy, GEH.

6. The Spy, a Romantic Story of the Civil War, March 9, 1907, $600 \mathrm{ft}$., drama.

7. A Curious Dream, March 16, 1907, 300 ft., comedy.

8. Retribution or the Brand of Cain, March 30, 1907, $770 \mathrm{ft}$., drama.
9. The Belle of the Ball, March 30, 1907, $475 \mathrm{ft}$. comedy.

10. The Hero, April 6, 1907, $250 \mathrm{ft}$., drama.

11. Amateur Night; or, "Get the Hook," April 13, 1907, $500 \mathrm{ft}$., comedy, GEH (excerpt).

12. On the Stage, April 27, 1907, $715 \mathrm{ft}$., drama.

13. The Flat Dwellers, April 27, 1907, $400 \mathrm{ft}$., comedy. Note: this film was released and copyrighted in 1906, then recopyrighted and rereleased in 1907 at a length 50 feet shorter than the 1906 release.

14. The Pirate's Treasure a Sailor's Love Story, May 4, 1907, $800 \mathrm{ft}$., drama

15. The Stolen Pig, May 18, 1907, 450 ft., comedy, LOC

16. A Square Deal or, the End of the "Bad Men," May 25, 1907, $425 \mathrm{ft}$., drama.

17. A Horse of Another Color, May 25, 1907, 425 ft., comedy.

18. "Forty Winks;" or, a Strenuous Dream, June 1, 1907, $270 \mathrm{ft}$., comedy.

19. One Man Baseball, June 1, 1907, $280 \mathrm{ft}$. comedy.

20. The Bunco Steerers and How They Were Caught, June 8, 1907, 425 ft., comedy.

21. How to Cure a Cold, June 8, 1907, $550 \mathrm{ft}$. comedy.

22. The Slave, June $15,1907,550 \mathrm{ft}$., drama

23. The Awkward Man or, Oh! So Clumsy, June 22, 1907, $300 \mathrm{ft}$., comedy.

24. The Bandits or, an Adventure in Italy, June 29, 1907, $550 \mathrm{ft}$., drama.

25. The Wrong Flat or a Comedy of Errors, July 6, 1907, $625 \mathrm{ft}$., comedy.

26. Lost in an Arizona Desert, July 13, 1907, 600 ft., drama.

27. The Window Demonstration, July 13, 1907, $275 \mathrm{ft}$., comedy, GEH.

28. Lightning Sketches, July 27, 1907, 600 ft., comedy, NFA

29. Father's Quiet Sunday, July 20, 1907, 625 ft., comedy.

30. Elks' Convention, July 27,1907 , including parade and grandstand, sold in lengths $400-1,000 \mathrm{ft}$. , actuality.

31. The Athletic American Girls, August 3, 1907, $400 \mathrm{ft}$., comedy.

32. The Boy, the Bust and the Bath, August 3, 1907, 425 ft., comedy, MOMA, NFA, GEH.

33. The Bargain Fiend; or, Shopping à-la-Mode, August 10, 1907, $500 \mathrm{ft}$., comedy.

34. The White Man's First Smoke; or, Puritan Days in America, August 10, 1907, $500 \mathrm{ft}$., comedy.

35. A Double-Barreled Suicide, August 10, 1907, $280 \mathrm{ft}$., comedy.

36. The Easterner a Tale of the West, August 17, 1907, 475 ft., drama, NFA. 
37. The Starving Artist or Realism in Art, August 17, 1907, $650 \mathrm{ft}$., comedy

38. 2,000 Miles without a Dollar, August 24, 1907 $430 \mathrm{ft}$., drama.

39. Man, Hat and Cocktail, August 24, 1907, 400 ft., comedy.

40. Bathing under Difficulties, August 31, 1907, $500 \mathrm{ft}$., comedy.

41. The Baby Elephant, August 31, 1907, 425 ft., comedy.

42. The Fountain of Youth, September 7, 1907, $375 \mathrm{ft}$., drama.

43. Liquid Electricity; or, the Inventor's Galvanic Fluid, September 7, 1907, $470 \mathrm{ft}$., comedy, MOMA, NFA.

44. The Ghost Story, September 14, 1907, $230 \mathrm{ft}$., drama.

45. Cast Up by the Sea, September 14, 1907, 435 $\mathrm{ft}$., drama

46. The Disintegrated Convict, September 21, 1907, $425 \mathrm{ft}$., comedy.

47. The Burglar, or a Midnight Surprise, September 28, 1907, $440 \mathrm{ft}$., comedy.

48. The Mill Girl-A Story of Factory Life, September 28, 1907, $700 \mathrm{ft}$, drama, MOMA, NFA.

49. Purchasing an Automobile, October 5, 1907 , $700 \mathrm{ft} .$, comedy.

50. The Gypsy's Warning, October 5, 1907, 285 $\mathrm{ft}$., drama.

51. The Piker's Dream a Race Track Fantasy, October 12, 1907, 700 ft., drama.

52. The Masquerade Party, October 19, 1907, 530 ft., drama.

53. The Inquisitive Boy, or Uncle's Present, October 26, 1907, $500 \mathrm{ft}$., comedy.

54. The Veiled Beauty or, Anticipation and Realization, October 26, 1907, $600 \mathrm{ft}$., comedy.

55. The Kitchen Maid's Dream, November 2, 1907, $400 \mathrm{ft}$., comedy.

56. The Soldier's Dream, November 2, 1907, 300 $\mathrm{ft}$., drama

57. The Twin Brother's Joke, November 9, 1907, $600 \mathrm{ft}$., comedy.

58. A Little Hero, November 9, 1907, $300 \mathrm{ft}$., drama.

59. A Fish Story, November 16, 1907, $450 \mathrm{ft}$., comedy.

60. A Crazy Quilt, November 16, 1907, $400 \mathrm{ft}$., comedy.

61. The Despatch Bearer or, through the Enemy's Lines, November 23, 1907, $725 \mathrm{ft}$., drama.

62. Under False Colors, November 30, 1907, 575 $\mathrm{ft}$., comedy.

63. The Burglar and the Baby, November 30, 1907, 375 ft., drama.
64. The Need of Gold, December 7, 1907, $475 \mathrm{ft}$., drama.

65. Laughing Gas, December 7, 1907, 400 ft., comedy.

66. A Tale of the Sea, December 14, 1907, 750 $\mathrm{ft}$., drama.

67. A Night in Dreamland a Fairy Fantasy, December 21, 1907, 500 ft., drama.

68. A Clown's Love Story, December 21, 1907, $325 \mathrm{ft}$., drama.

69. The Miser's Hoard, December 28, 1907, 350 ft., drama.

70. Work Made Easy, December 28, 1907, 500 ft., comedy.

\section{Acknowledgments}

This article would not have been possible without the support and guidance of Jay Leyda and George Pratt. Allan Bobey of George Eastman House and Emily Sieger of the Library of Congress facilitated my viewing of Vitagraph films held by their respective institutions. Pat Loughney of the Library of Congress generously shared his insights regarding paper print materials. Tom Gunning and Eileen Bowser gave helpful comments on an earlier draft of this article and Dan Leab was a source of encouragement for my presentation of this paper at a scholarly seminar.

\section{Notes}

1 See especially National Film Archives, London 1982.

2 The two books written on Vitagraph fall short of providing a significant analysis of the company. Smith 1952 (a founder of Vitagraph) contains incorrect dates and inaccurate recollections. Slide 1976 relies on written documents and memories of the company's survivors and dependents but is concerned more with the personalities involved than with Vitagraph's creative importance or economic position in the industry. Musser 1983 focuses on the company's uneasy relationship with the Edison Manufacturing Company in the 1890s.

3 New York Clipper, January 6, 1906, p. 1188

4 Ibid., September 7, 1907, p. 796.

5 Views and Film Index, April 20(?) or 27(?), 1907 (pages out of order in unbound volume).

6 Ibid.. August 25, 1906. Prior to this, Vitagraph had a small studio with a skylight in the Morse Building at 140 Nassau Street in Manhattan and then in the Morton building, 110-116 Nassau Street. $7 \mathrm{lbid}$.

$8 \mathrm{lbid}$.

9 In later years, Vitagraph used studio lighting to great dramatic effect. In Proving His Love or, the Ruse of a Beautiful Woman (June 1911), an actress tests the affections of her suitors by pretending to disfigure her face. The confrontations take place in her living room The window is on the left, the midground has flowers on a table, and the actress is sitting in a chair on the right. Two suitors successively approach her; as she exposes her disfigurement, they recoil in horror. Her true love, the newspaper reporter Stanwood, approaches. He bends down, shadows falling across his face. She blindfolds him and takes off her makeup to show her disfigurement was only a ploy. Thinking he is rejected, Stanwood retreats into the background, into the darkness of the doorway. Slowly the actress pulls him back into the frame, into the light, and they embrace. The darkness and light function as dramatic protagonists that add visual intensity to the emotional relationships.

10 New York Dramatic Mirror, November 14, 1908, p. 10.

11 Letter from Benjamin Hampton to Albert Smith, March 3, 1916, discussing Vitagraph's international importance, in Box 4, Albert Smith papers, University of California, Los Angeles. It is possible by this time that Vitagraph had reached the height of its growth in produc- 
tion facilities. Around this time a series of agreements changed ownership of Vitagraph, affected its distribution network, and caused Blackton to leave the company. These factors may have contributed to the peaking of Vitagraph's growth, even though the company survived for ten more years

12 For discussion of models of film production, see also Janet Staiger's publications.

13 G. M. "Broncho Billy" Anderson may have directed some Vitagraph films in 1902, and Smith worked with Blackton taking trick and actuality films. Other cameramen did take other films, but under their supervision. See Musser 1983.

14 Vitagraph directors were not regularly publicized until June 1912 , so it is difficult to attribute specific films to given directors before that time.

15 New York Dramatic Mirror, November 14, 1908, p. 10.

18 Moving Picture World, December 12, 1908, p. 487

17 "How Motion Pictures Are Made in Great Flatbush Plant," Brooklyn Daily Eagle, July 30, 1911, p. 7.

18 These statistics are arrived at by comparing the figures in Paul Spehr's and Eileen Bowser's articles on Biograph productions with my own statistics compiled for the 1905-1909 Vitagraph period together with the 1910-1915 Vitagraph filmography listed in Slide 1976.

19 New York Dramatic Mirror, November 14, 1908, p. 10.

20 New York Clipper, September 23, 1905, p. 795. The first four theaters were in Manhattan and the following two in Brooklyn.

21 Aldo Bernardini, Italian film historian, in letter to me, July 31,1980.

22 Letter from Ronald Reader, Paris, to Albert Smith, February 2, 1909 , in Box 2. Albert Smith papers, University of California, Los Angeles.

23 Letter from George (Vitagraph Company manager) to Albert Smith, New York, February 3, 1909, in Box 2, Albert Smith papers University of California, Los Angeles.

24 Moving Picture World, March 7, 1908, pp. 186-187, and February 1908 correspondence in Box 2, Albert Smith papers, University of California, Los Angeles.

25 Price Waterhouse accounts report for five years to 1913, Box 2, Albert Smith papers, University of California, Los Angeles. Also, in letters between "Vic" in New York and Albert Smith in Paris, February 11 and 18,1908 , the international shipping, printing, and safekeeping of negatives, such as The Last Cartridge, are discussed.

26 Donald Crafton, in letter to me, 1982.

27 See also Musser 1983.

$28 \mathrm{Ibid} .$, p. 38. These films survive in the Library of Congress paper print collection.

29 Brooklyn Daily Eagle, September 6, 1903, p. 8.

30 Moving Picture World, April 6, 1907, p. 71

31 These statistics are based on Spehr's and Bowser's articles on production at Biograph and on my analysis of the production at

Vitagraph during the corresponding period

32 New York Clipper, September 8, 1906, p. 784

$33 \mathrm{lbid}$

34 Ibid., May 5, 1906, p. 324; May 12, 1906, p. 352; May 19, 1906, p. 380

35 For accounts of the authentic and fake films of the San Francisco earthquake, see Fielding 1972:23, 24, 42, 49, 50.

36 New York Clipper, October 13, 1906, p. 920

37 Ibid.

38 Ibid., October 14, 1905, p. 880.

39 Views and Film Index, May(?) 11, 1907 (pages out of order in unbound volume).

40 New York Clipper, September 21, 1907, p. 856

41 Ibid., November 2, 1907, p. 1040

$42 \mathrm{Ibid}$., November 16, 1907, p. 1096

43 Ibid., December 28, 1907, p. 1256

44 Ibid., September 7, 1907, p. 796.

45 Ibid., January 5, 1907, p. 224.

46 Full-length view is defined as a character appearing within the full extent of the set, with space above the character's head, and a foreground area showing in front of his feet.

47 Tom Gunning has pointed out that Griffith avoided theatrical posing to achieve naturalism even if it meant losing some of the characters' facial and frontal body expressions.

48 See Vardac 1968, especially chap. 2, "The Melodrama: Cinematic Conceptions and Screen Techniques," pp. 20-22 and 46-48 ["The device of the dual box set was an old one. ... Two rooms were simultaneously placed upon the stage. ..."]; Fell 1974, especially chap. 2, "Dissolves by Gaslight," pp. 20-23; and Hagan 1982:240.

49 For a detailed discussion of camera movement in early cinema, see Gartenberg 1980:1-16, 1982:169-180.

\section{References}

- Allen, Robert C

1979 Motion Picture Exhibition in Manhattan 1906-1912: Beyond the Nickelodeon. Cinema Journal 18(2):2-15

- Bowser, Eileen

1981 Production Patterns of the Biograph Company 1907-1916. Paper presented at the Society for Cinema Studies Meeting City University of New York.

1983 Toward Narrative: 1907/The Mill Girl. In Film before Griffith John L. Fell, ed. Berkeley: University of California Press.

- Crafton, Donald

1982 Before Mickey: The Animated Film 1898-1928. Cambridge Mass.: MIT Press.

- Fell, John L.

1974 Film and the Narrative Tradition. Norman, Okla.: University of Oklahoma Press.

- Fielding, Raymond

1972 The American Newsreel 1911-1967. Norman, Okla.: University of Oklahoma Press.

- Gartenberg, Jon

1980 Camera Movement in Edison and Biograph Films, 1900-1906. Cinema Journal 19(2):1-16.

1982 Camera Movement in Edison and Biograph Films 1900-1906. In Cinema 1900/1906: An Analytical Study. Prepared by National Film Archives, London. Brussels: Fédération Internationale des Archives du Film.

- Glover, Katherine

1906 Moving Pictures Amuse and Instruct. The Brooklyn Daily Eagle, September 9

- Hagan, John

1982 Simultaneous Action in Film, 1900-1906. In Cinema 1900/ 1906: An Analytical Study. Prepared by National Film Archives, London. Brussels: Fédération Internationale des Archives du Film.

- Macgowan, Kenneth

1965 Behind the Screen: The History and Technique of the Motion Picture. New York: Delta

- Musser, Charles

1982 Establishing the Foundations for Hollywood's Mode of Representation. Paper presented at the Society for Cinema Studies Meeting, Los Angeles, California.

1983 American Vitagraph 1897-1901. Cinema Journal 22(3):4-46.

- National Film Archives, London, preparer

1982 Cinema 1900/1906: An Analytical Study. Brussels: Fédération Internationale des Archives du Film. 2 vols.

- Sadoul, Georges

1951 Histoire Générale du Cinéma. Paris: Denoël. Vol. 3

- Slide, Anthony

1976 The Big V: A History of the Vitagraph Company. Metuchen, N.J.: Scarecrow Press.

- Smith, Albert E.

1952 Two Reels and a Crank. Garden City, N.Y.: Doubleday.

- Spehr, Paul C

1980 Filmmaking at the American Mutoscope and Biograph Company, 1900-1906. Quarterly Journal of the Library of Congress $37(3-4)$.

- Vardac, A. Nicholas

1968 Stage to Screen: Theatrical Method from Garrick to Griffith New York: B. Blom. 